\title{
2-D Tissue Motion Compensation of Synthetic Transmit Aperture Images
}

\section{Gammelmark, Kim Løkke; Jensen, Jørgen Arendt}

Published in:

IEEE Transactions on Ultrasonics, Ferroelectrics and Frequency Control

Link to article, DOI:

10.1109/TUFFC.2014.2948

Publication date:

2014

Document Version

Publisher's PDF, also known as Version of record

Link back to DTU Orbit

Citation (APA):

Gammelmark, K. L., \& Jensen, J. A. (2014). 2-D Tissue Motion Compensation of Synthetic Transmit Aperture Images. IEEE Transactions on Ultrasonics, Ferroelectrics and Frequency Control, 61(4), 594-610.

https://doi.org/10.1109/TUFFC.2014.2948

\section{General rights}

Copyright and moral rights for the publications made accessible in the public portal are retained by the authors and/or other copyright owners and it is a condition of accessing publications that users recognise and abide by the legal requirements associated with these rights.

- Users may download and print one copy of any publication from the public portal for the purpose of private study or research.

- You may not further distribute the material or use it for any profit-making activity or commercial gain

- You may freely distribute the URL identifying the publication in the public portal 


\section{IEEE TRANSACTIONS ON \\ ULTRASONICS, FERROELECTRICS, AND FREQUENCY CONTROL}

A PUBLICATION OF THE IEEE ULTRASONICS, FERROELECTRICS, AND FREQUENCY CONTROL SOCIETY

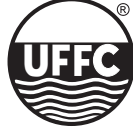

APRIL 2014

VOLUME 61

NUMBER 4

ITUCER

[ISSN 0885-3010]
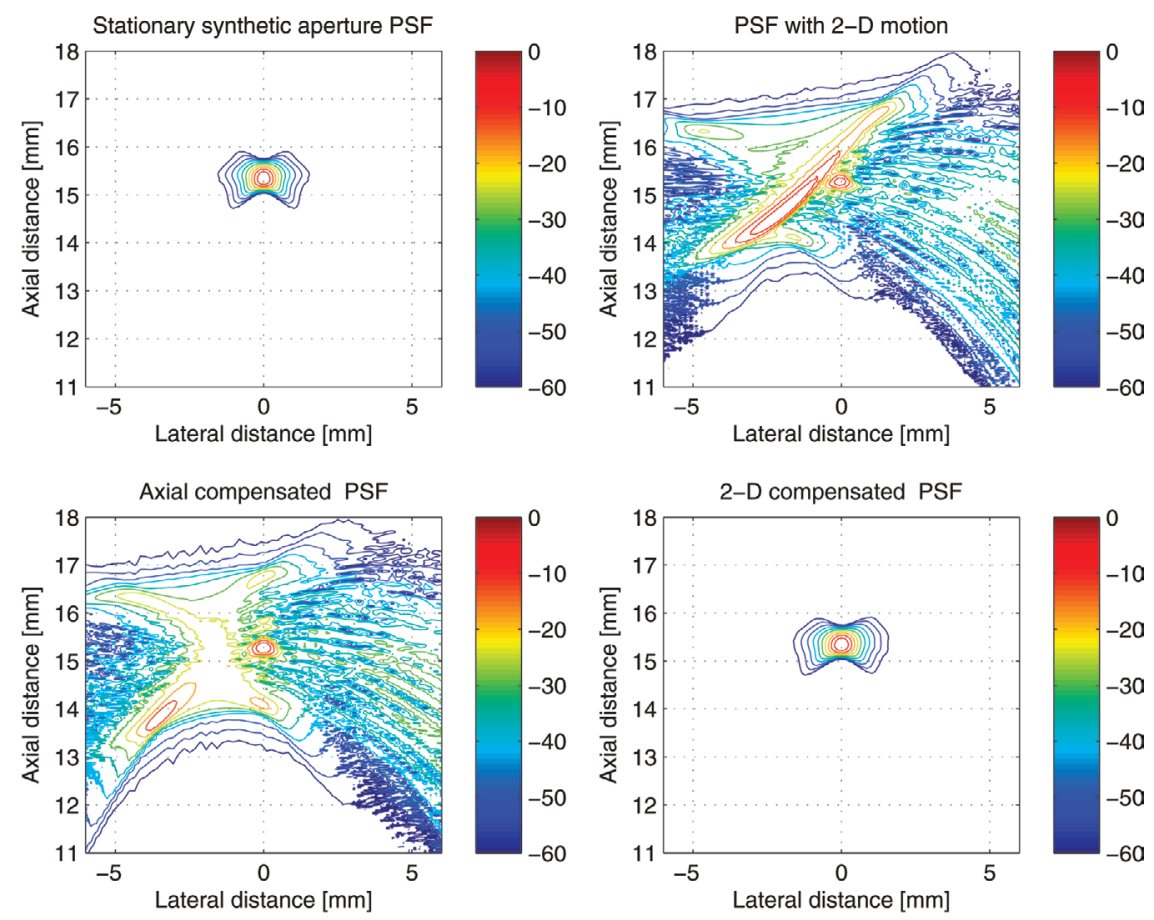

Abdominal TMS Imaging - Frame 21 of 33
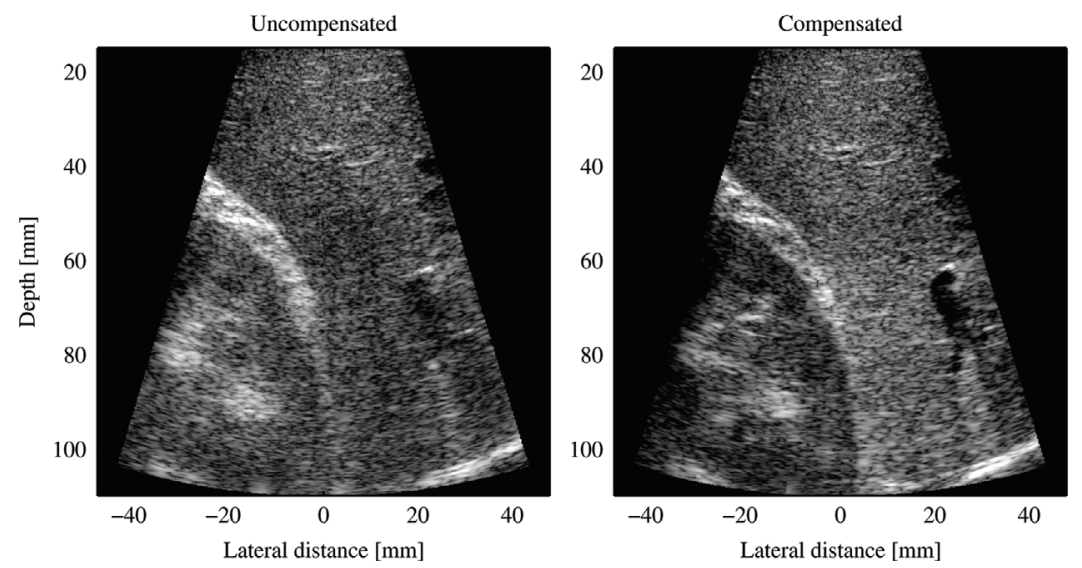

Access the journal with its multimedia contents online at: http://www.ieee-uffc.org/tr/ 8 as 


\section{2-D Tissue Motion Compensation of Synthetic Transmit Aperture Images}

The accompanying paper describes a new method for reducing motion artifacts in synthetic aperture (SA) images. These are acquired over a number of pulse emissions and then focused by combining the received signals for all emissions. The acquisition time for the imaging lines is therefore longer than for traditional images, and this can lead to defocusing effects from tissue motion. SA images often have a high resolution, on the order of a wavelength both axially and laterally, and tissue motion in either direction thus affects the image quality. This is illustrated in the top four graphs on the front cover, which depict the point spread function (PSF) from a lineararray SA imaging system with 128 emissions acquired at a $5 \mathrm{kHz}$ pulse repetition frequency. The top-left graph shows the ideal PSF and the right graph illustrates the PSF for a tissue velocity of $\left(v_{\text {axial }}, v_{\text {lateral }}\right)=(10.6,10.6)$ $\mathrm{cm} / \mathrm{s}$. Employing a purely axial motion compensation gives the PSF on the lower left, which still has significant distortion of the side lobes. Employing a 2-D motion compensation yields the PSF shown on the lower right, where the ideal PSF is nearly recovered.

A duplex SA imaging scheme with 2-D motion estimation was developed in the accompanying paper and employed in the grayscale in vivo images shown at the bottom. They show a longitudinal section of the right liver lobe with a cross-sectional view of the hepatic vein (right), longitudinal section of a portal vein branch (top center), the kidney, and diaphragm at the lower-right corner. The left image is without compensation and the right has been compensated using the new 2-D approach. A clear improvement can be seen for the hepatic vein and the

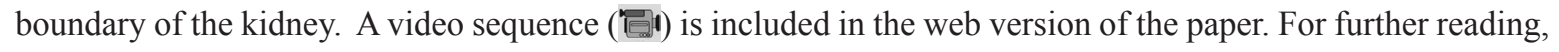
please see the accompanying article on page 594 of this issue.

Images courtesy of Kim Løkke Gammelmark and Jørgen Arendt Jensen. K. L. Gammelmark was with and J. A. Jensen is with the Center for Fast Ultrasound Imaging, Department of Electrical Engineering, Technical University of Denmark, Kgs. Lyngby, Denmark. K. L. Gammelmark is now with Dako Denmark A/S, Glostrup, Denmark. 